\title{
SOLID SOLUTIONS FORMATION MECHANISM IN CORDIERITE- MULLITE GLASS MATERIALS DURING CERAMIZATION
}

\author{
Oksana Savvova $^{1,}{ }^{凶}$, Hennadiy Voronov ${ }^{1}$, Olena Babich $^{2}$, Oleksii Fesenko $^{1}$, \\ Sviatoslav Riabinin ${ }^{3}$, Robert Bieliakov ${ }^{4}$
}

https://doi.org/10.23939/chcht14.04.583

\begin{abstract}
Relevance of the development of high-strength glass-ceramic coatings obtained by resource-saving technology for protective elements has been established. Structure formation mechanism in magnesium aluminosilicate glasses during heat treatment has been analyzed. Selection of the system was substantiated, model glasses and glass-ceramic materials on its base have been developed. Patterns of structure regularity and formation of the phase composition of glass-ceramic materials during their ceramization have been investigated. It was established that the presence of crystalline phase of mullite after melting leads to formation of the primary crystals and allows the formation of the fine crystalline structure under conditions of the low-temperature heat treatment at the nucleation stage. Developed high-strength glass ceramic materials can be used as a base in creating protective elements for specialpurpose vehicles by energy-saving technology.
\end{abstract}

Keywords: glass-ceramics, structure, solid solutions, cordierite, mullite, heat treatment.

\section{Introduction}

The task of creating polyfunctional materials, including the ones that combine high strength, thermal, chemical and electrical properties with durability towards variable factors, is of very high relevance nowadays. A special place among the perspective materials is taken by high-strength glass ceramics with high resistance to the

\footnotetext{
${ }^{1}$ O.M.Beketov National University of Urban Economy in Kharkiv, 2

${ }^{3}$ Research Institution "Ukrainian Scientific Research Institute of Ecological Problems"

6, Bakulina St., 61166 Kharkiv, Ukraine

3 National Technical University "Kharkiv Polytechnic Institute"

2, Kyrpychova St., 61002 Kharkiv, Ukraine

${ }^{4}$ Military Institute of Telecommunications and Information

Technologies

45/1, Moskovskaya St., 01011 Kiev, Ukraine

$\triangle_{\text {savvova_oksana@ukr.net }}$

(C) Savvova O., Voronov S., Babich O., Fesenko O., Riabinin S., Bieliakov R, 2020
}

high-energy ionizing, electromagnetic, microwave radiation; radiotransparent and low-weight glass ceramics with a significant impact viscosity [1].

Thanks to the combination of high mechanical strength and the ability to absorb impact loads, fire resistance, chemical durability, relatively small density and lower costs, glass ceramics in the $\mathrm{MgO}-\mathrm{Al}_{2} \mathrm{O}_{3}-\mathrm{SiO}_{2}$ (M-A-S) system, based on natural raw materials [2], are potentially usable in creating protective materials used under conditions of high mechanical and thermal loads [2]. However, the high values of density and temperaturetime regimen of melting of the abovementioned glass ceramics does not allow to obtain them under relatively low-temperature thermal treatment. Development and implementation of competitive high-strength glassceramic materials obtained by a resource saving technology for protective elements allows to solve the major problem of special-purpose vehicles survivability.

Forecasting of the structure and phase composition is one of the main tasks when creating new glass ceramic materials on the base of M-A-S system and during their use under energy destructive factors. However, the presence of a significant amount of melt in the synthesized materials causes essential unpredictability of structure formation in the given phase composition due to unknown limits and rates of dissolution of different crystalline phases of the material in it [3]. Therefore, identification of the mechanism of nucleation and crystallization processes in the glass materials of the M-A-S system in the presence of glass melt requires further research and scientific substantiation.

Investigations of glass formation and crystallization in a magnesium oxide-alumina-silica system conducted by $\mathrm{N}$. Toropov and N. Syrajiddinov allow to determine that metastable solid solutions having a quartz structure in the temperature range of $1073-1273 \mathrm{~K}$ crystallize as the primary crystalline phase in the system. The increase of crystallization temperature leads to the increase in the amount of primary crystalline phase and formation of the crystals of high cordierite and cristobalite. At higher firing temperatures $(\approx 1473 \mathrm{~K})$, decomposition of metastable solid 
solutions and transformation of high cordierite into a low cordierite occur. However, decomposition temperature of solid solutions and polymorph transformation of high cordierite, as in case of their formation, changes depending of the chemical composition of the glasses [4]. The change in composition of metastable phases formed during glass crystallization to rapid occurrence of cordierite $\left(\mathrm{M}_{2} \mathrm{~A}_{2} \mathrm{~S}_{5}\right)$ and mullite $\left(\mathrm{A}_{3} \mathrm{~S}_{2}\right)$, which have different properties (Table 1), influences the performance characteristics of the glassceramics significantly.

Table 1

Properties of crystalline phases of mullite and cordierite

\begin{tabular}{|l|c|c|}
\hline \multicolumn{1}{|c|}{ Property } & Mullite & Cordierite \\
\hline Density $\rho, \mathrm{g} / \mathrm{cm}^{3}$ & $3.0-3.2$ & $2.57-2.59$ \\
\hline Dielectric constant, $\varepsilon_{298 \mathrm{~K}}, f=1 \mathrm{MHz}$ & 6.6 & 5.0 \\
\hline Compression strength $\sigma_{\text {comp }}, \mathrm{MPa}$ & 270 & 245 \\
\hline Young modulus $E, \mathrm{GPa}$ & 220 & 139 \\
\hline Poisson ratio $\mu$ & 0.27 & 0.31 \\
\hline Vickers hardness $\mathrm{H}, \mathrm{MPa}$ & 11.0 & 8.2 \\
\hline Fracture toughness $K_{I C}, \mathrm{MPa} \cdot \mathrm{m}^{\mathrm{I} / 2}$ & 2.6 & 2.3 \\
\hline Temperature coefficient of linear expansion $\alpha_{298-1073 \mathrm{~K}} \cdot 10^{6}, \mathrm{deg}^{-1}$ & 5.0 & 1.5 \\
\hline
\end{tabular}

One of the effective ways of improving the functional properties of glass-ceramic materials is modification of their chemical composition, in particular by introducing combined crystallization catalysts and fluxing components $[5,6]$. Nanostructuring of magnesium aluminosilicate glass-ceramic materials in the process of their ceramization can be provided by adding thermodynamically non-coexisting components to the composition of initial glass and limiting synthesis temperature by specific values [3].

Complexity of structure formation of magnesium aluminosilicate materials is due to distortion of cordierite structure, which is caused by re-allocation of $\mathrm{Si}$ and $\mathrm{Al}$ atoms in cordierite-indialite $\mathrm{Si}_{5} \mathrm{AlO}_{18}$ rings. Their irregular allocation leads to formation of hexagonal highly symmetrical structure of indialite, whereas their regular allocation forms the structure of lower symmetry level of highly distorted cordierite. Therefore, index of distortion is a level of the structure regularity, of $\mathrm{Al}$ and $\mathrm{Mg}$ atoms allocation between the rings at irregularity-regularity transition. While heating to high temperatures, cordierite transforms to indialite and continuously undergoes a series of structural changes which can be described as irregularity-regularity [7].

A. Miashiro [8] suggests naming cordierite with the maximum extent of distortion "perdistortional", strongly distorted cordierite with the value of distortion index of $\Delta>0.29^{\circ}$, whereas the mineral having a structure distortion between indialite $\left(\Delta=0^{\circ}\right)$ and strongly distorted cordierite should be named "subdistortional" cordierite $\left(0.29^{\circ}>\Delta>0^{\circ}\right)$.

Majority of natural and synthetic cordierite materials are structurally placed between indialite and high strongly distorted cordierite $\left(\Delta=0.29-0.31^{\circ}\right)$, and belong to two classes:
- high subdistorted cordierite $0.29^{\circ}>\Delta>0^{\circ}$, which has a pseudohexagonal structure (orthorhombic), stable at high temperatures;

- low subdistorted cordierite is an intermediate between low indialite and low strongly distorted cordierite $\left(\Delta=0.29-0.31^{\circ}\right)$, and has a pseudohexagonal structure, unstable at any temperature.

Considering the complexity of the classification of cordierites suggested by A. Mishiro, the simplified version of classification is often used in academic literature. Thus, the form of cordierite stable at high temperatures is called $\alpha$-cordierite. According to the classification by A. Miashiro, it can be designated as high subdistorted cordierite or as high indialite. The same card 13-239 corresponds to high cordierite and indialite mineral in ICDD card index of powder diffraction pattern [9]. There are two cards in ASTM card index attributed to cordierite, 13-294, 12-303. All of these cordierites have orthorhombic structure and it is possible to determine the type of this compound only if the values of lattice parameters or structure distortion indices are provided.

$\mathrm{N}$. Toropov refers to distortion index as ordering index, meaning that random hexagonal structure with the index of $\Delta=0^{\circ}$ transforms to the ordered structure of pseudohexagonal rombic cordierite, with $\Delta$ taking on maximal values [4]. N. Toropov and coauthors indicate that the maximum ordering was obtained for a specimen of stoichiometric cordierite which was heat-treated at $1673 \mathrm{~K}$ during $120 \mathrm{~h}$; in this case $\Delta \approx 0.20^{\circ}$. With further increase of temperature, the value of $\Delta$ index decreases. In the vicinity of the incongruent melting point, the strength degradation and the reverse transition of low-symmetry rhombic cordierite to hexagonal cordierite occur. As a result of long-term heat treatment at $1673 \mathrm{~K}$, low (lowsymmetry) rombic cordierite stable at temperatures below 
$1713 \mathrm{~K}$ was obtained from high (high-symmetry) hexagonal cordierite. With the increase of temperature to $1733 \mathrm{~K}$, reverse transition from the unordered cordierite is observed. It has also been established that polymorphic transformation related to the formation of rhombic cordierite is accompanied by partial amorphization of the crystalline structure occurring with a significant rate in a narrow temperature interval.

Determining the mechanism of the formation of cordierite structure transitions related to its complex polymorphism and special cases of formation of ordered and unordered structures in magnesium aluminosilicate glass materials during their ceramization will allow to develop the processing principles of manufacturing and compositions of low-weight mullite-cordierite glass-ceramic materials under conditions of low-temperature heat treatment.

The aim of this work is to establish the formation mechanism of the solid solutions in magnesium aluminosilicate glass materials during their ceramization.

\section{Experimental}

\subsection{Investigation Methods}

Physico-chemical methods of testing model glasses used in the work were: XRD-diffraction (DRON-3M diffractometer), differential-thermal (Paulik-Paulik-Erdey derivatograph), gradient-thermal (gradient tube-type furnace), petrographic (NU-2E optical microscope) analysis methods. Viscosity of glass was measured by the string elongation method with a viscosimeter by "Institute of Glass" LTD. The structure of glasses post melting was investigated by LCD-Micro microscope.

Ordering index of cordierite structure, $\Delta$, was determined as a difference in transition points (131) by XRD lines and (511)- and (421)-lines. Reflexes of cordierite were defined $A, B$ and $D$ (from the less to greater angles). When another angle appears between the angles $B$ and $D$, it is defined as $C$ [8].

$$
\Delta=2 \theta D-\frac{2 \theta A+2 \theta B}{2}
$$

Fracture toughness, $K_{I C}$, (failure viscosity) was determined by TMV-1000 apparatus by indenting Vickers pyramid under the load of $49 \mathrm{~N}$ by 5 measurements and calculated with Niihari semi-stoichiometric dependency. Impact viscosity of glass ceramic was determined by the energy needed to crush a specimen freely positioned on the supports, at a single pendulum hit.

\subsection{Development of Magnesium Aluminosilicate Glasses Composition}

Implementation of high mechanical and thermal durability of magnesium aluminosilicate glass-ceramic materials is viable via provision of fine bulk crystallization of the initial glass with the formation of crystalline phases of mullite and cordierite by directional low-temperature crystallization under conditions of twostage heat treatment. To attain the objective, compositions of glasses in the M-A-S system in the region of mullite and cordierite crystallization with certain content of phase-forming components and modifying additives were selected (Table 2).

Bulk-crystallized structure of initial glasses is provided by introducing $\mathrm{TiO}_{2}$ and $\mathrm{ZrO}_{2}$ to the crystallization catalysts that are conventional for the experimental system. Introduction of $\mathrm{P}_{2} \mathrm{O}_{5}$ to the composition of the materials will allow to accelerate the crystallization processes of cordierite glass, and, along with the presence of $\mathrm{ZnO}$ and $\mathrm{CeO}_{2}$, will promote the formation of fine interconnected structure formed by a liquation mechanism in the low-temperature range. Along with that, the presence of $\mathrm{P}_{2} \mathrm{O}_{5}$ in the structure of the materials will allow reducing the strain of the material and thermomechanical stresses occurring under impact energy absorption. Introduction of $\mathrm{B}_{2} \mathrm{O}_{3}$ to the composition of glass matrix will influence the increase in the rate of sound wave propagation in the material, and, along with the presence of $\mathrm{CaO}, \mathrm{SrO}$, will allow increasing the impact viscosity. $\mathrm{B}_{2} \mathrm{O}_{3}$ and $\mathrm{K}_{2} \mathrm{O}$ were introduced to the initial glasses to reduce their density and structural viscosity.

Table 2

Ratio of phase-forming components and amount of catalysts in the glass compositions

\begin{tabular}{|c|c|c|c|c|c|c|c|c|c|c|}
\hline \multirow{2}{*}{$\begin{array}{c}\text { Chemical composition, } \\
\text { wt } \%\end{array}$} & \multicolumn{10}{|c|}{ Glass marking } \\
\hline & KSK-1 & KSK-2 & KSK-3 & KSK-4 & KSK-5 & KSK-6 & KSK-7 & KSK-8 & KSK-9 & KSK-10 \\
\hline $\mathrm{M}: \mathrm{A}: \mathrm{S}$ & $1.0: 2.5: 5.0$ & $1.0: 2.5: 6.5$ & $1.0: 2.5: 4.3$ & $1.0: 2.0: 3$. & $1.0: 3.0: 5$ & $1.0: 1.7: 3.7$ & $1.0: 2.6: 4.5$ & $1.0: 3.0: 5$ & $1.0: 2.7: 4$ & $1.0: 3.2: 5.6$ \\
\hline $\mathrm{ZnO}$ & - & - & - & - & 2.5 & - & - & 2.5 & - & - \\
\hline $\mathrm{TiO}_{2}$ & 2.5 & 2.5 & 3.0 & 5.0 & 3.0 & 8.0 & 3.0 & 2.0 & 2.0 & 2.0 \\
\hline $\mathrm{ZrO}_{2}$ & - & - & - & - & - & 1.0 & 2.0 & 2.5 & - & 1.5 \\
\hline $\mathrm{CeO}_{2}$ & - & - & - & 0.5 & 0.5 & - & - & - & - & 0.5 \\
\hline $\mathrm{P}_{2} \mathrm{O}_{5}$ & - & - & - & - & - & 3.0 & 3.0 & - & - & 2.0 \\
\hline $\mathrm{B}_{2} \mathrm{O}_{3}$ & 5.0 & 5.0 & - & - & - & - & - & - & - & 2.0 \\
\hline
\end{tabular}


To establish the region of initial glasses existence, the system $\mathrm{K}_{2} \mathrm{O}-\mathrm{RO}-\mathrm{RO}_{2}-\mathrm{P}_{2} \mathrm{O}_{5}-\mathrm{R}_{2} \mathrm{O}_{3}-\mathrm{SiO}_{2}$ was selected. The concentration limits (wt \%) were: $\mathrm{K}_{2} \mathrm{O} 0.0-7.0 ; \mathrm{MgO}$ 9.0-14.0; $\mathrm{CaO} 0.0-5.5 ; \mathrm{ZnO} 0.0-2.5 ; \mathrm{SrO} 0.0-4.0 ; \mathrm{TiO}_{2}$ 2.0-8.0; $\mathrm{ZrO}_{2} 0.0-2.5 ; \mathrm{CeO}_{2} 0.0-0.5 ; \mathrm{Al}_{2} \mathrm{O}_{3}$ 20.0-30.0; $\mathrm{B}_{2} \mathrm{O}_{3} \quad 0.0-5.0 ; \mathrm{P}_{2} \mathrm{O}_{5} \quad 0.0-3.0 ; \mathrm{SiO}_{2}$ 45.0-53.0. Natural mineral raw materials (Novoselivka sand, alumina, zircon, chalkstone, potassium feldspar), oxides with "chemically pure" marking $\left(\mathrm{ZnO}, \mathrm{TiO}_{2}, \mathrm{CeO}_{2}, \mathrm{MgO}\right)$ and other compounds (boric acid, strontium carbonate, disubstituted ammonia phosphate) were used to prepare the batch.

In this system, glasses of KSK series were synthesized in the same conditions at $1823-1873 \mathrm{~K}$ in corundum crucibles in the electrical furnace with molybdenum disilicide heaters with a gradual cooling in the furnace for $12 \mathrm{~h}$. According to the data of XRDdiffraction and petrographic analysis methods, the structure of glasses KSK-1, KSK-2, KSK-4, KSK-5, KSK-6 after melting is amorphous, while glasses KSK-3, KSK-7, KSK-9, KSK-8, KSK-10 possess microhetergeneous structure. KSK-9 glass material is fully translucent, thin mullite crystals with the size of $500 \mu \mathrm{m}$ in sheaf-shaped aggregates are observed visually in glass materials KSK-7, KSK-8 and KSK-10.

\section{Results and Discussion}

According to XRD and DTA results, the mechanism of structure formation and phase composition during heat treatment for experimental glass materials is significantly different for the materials of group I (KSK-1, KSK-2, KSK-3, KSK-4, KSK-5, KSK-6 and KSK-7) and group II (KSK-8, KSK-9 and KSK-10).

The results of investigation of phase composition change under conditions of thermal treatment allowed to establish that solid solutions having the structure of hightemperature quartz with diffraction maximum $(0.332 \mathrm{~nm})$ are observed as a primary crystalline phase in the range of low-temperature crystallization in the temperature region of $1053-1123 \mathrm{~K}$.

Further increase in treatment temperature to 1233 $1273 \mathrm{~K}$ leads to formation of solid solution on the basis of spinel and $\alpha$-cordierite. Intensive growth of crystals which are uniformly distributed in the bulk and crystallization of residual glass, including the transition of $\alpha$-quartz to $\alpha$ cristobalite are observed at $T_{c r 3}=1323-1423 \mathrm{~K}$. For the glasses of the group I, formation of solid solutions on the basis of $\alpha$-cordierite due to chemical reaction between $\alpha$-cristobalite and spinel according to the reaction: $2 \mathrm{MA}+5 \mathrm{~S}=\mathrm{M}_{2} \mathrm{~A}_{2} \mathrm{~S}_{5}$ occurs at indicated temperatures. For the glasses of group II, initially, cordierite is formed from mullite as a result of the reaction: $2 \mathrm{~A}_{3} \mathrm{~S}_{2}+6 \mathrm{MA}+$ $+5 \mathrm{~S}=3 \mathrm{M}_{2} \mathrm{~A}_{2} \mathrm{~S}_{5}(1273-1323 \mathrm{~K})$, which interacts with alumina to form mullite and spinel, according to the reaction $15 \mathrm{~A}+2 \mathrm{M}_{2} \mathrm{~A}_{2} \mathrm{~S}_{5}=4 \mathrm{MA}+5 \mathrm{~A}_{3} \mathrm{~S}_{2}$, when the temperature is increased to $1423 \mathrm{~K}$

Introduction of crystallization catalysts $\Sigma\left(\mathrm{TiO}_{2}\right.$, $\left.\mathrm{ZrO}_{2}, \mathrm{CeO}_{2}, \mathrm{P}_{2} \mathrm{O}_{5}\right)=2.0-7.5 \mathrm{wt} \%$ to the composition of the glasses of group II allows to decrease mullite crystallization temperature to $1373-1423 \mathrm{~K}$. Whereas for the glass of the system MAS with the composition, wt \%: $\mathrm{MgO}$ 8.9; $\mathrm{TiO}_{2}$ 9.95; $\mathrm{Al}_{2} \mathrm{O}_{3}$ 29.4; $\mathrm{SiO}_{2}$ 51.8, provided by the authors of [10], which is close to the glasses of group II in terms of the content of phase forming oxides, the occurrence of the above mechanism at the stage of cordierite and mullite crystallization is reported to be at 1323 and $1573 \mathrm{~K}$, respectively.

Based on the data obtained, the following technological regimes were selected for the glasses of group I: I stage- 1053-1093 K, $5 \mathrm{~h}$; II stage - 1323$1423 \mathrm{~K}, 5 \mathrm{~h}$. For the glasses of group II: I stage $-1123 \mathrm{~K}$, $5 \mathrm{~h}$; II stage $-1423 \mathrm{~K}, 5 \mathrm{~h}$. Materials of KSK series obtained by ceramic technology under conditions of lowtemperature heat treatment exhibit bulk fine structure with solid solutions on the basis of crystalline phase with total content of 30-85 vol \%: for the glasses of group I $\alpha$-cordierite $(15-75 \mathrm{vol} \%)$, mullite $(2-10 \mathrm{vol} \%)$, spinel (5-25 vol \%), quartz and corundum approximately $5 \mathrm{vol} \%$; for the glasses of group II - mullite (50$80 \mathrm{vol} \%$ ), cristobalite approximately $2 \mathrm{vol} \%$.

Considering the type and the amount of the crystalline phase formed as a result of heat treatment, glass-ceramic material of group II, KSK-10, and, for comparison purpose, materials of group I, KSK-4 and KSK-6, were selected for further research (Table 3). To establish the features of solid solution formation under conditions of low-temperature crystallization in experimental materials, their heat treatment at characteristic temperatures of crystalline phases formation has been carried out.

Results of investigation allow to establish the formation of cordierite-mullite solid solutions for all developed materials, as evidenced by a shift of diffraction maxima towards lower angles compared to the standard ones according to ASTM [9] (Figs. 1-3). In this case, dissolution of magnesium oxide occurs with the increase of identity period of the solvent - aluminum oxide.

After heat treatment at $1173 \mathrm{~K}$, splitting of maximum in the $2 \Theta$ angle range of 32 and $33^{\circ}$ for glassceramic materials KSK-4 (Fig. 1) and KSK-6 (Fig. 2) is clearly observed (for $\mathrm{CrK} \alpha$ radiation). Location of secondary angles $A, B$ and $D$ for the indicated materials is likely a reflex of planes (511), (421), (131), and $C$ is a reflex of (421) of rhombic cordierite crystal lattice. Distance between $A, B$ and $D$ is increased with the increase in distortion extent of the system. After heating the experimental material to the temperature of $1273 \mathrm{~K}$, all secondary maxima coalesce into a single one which cor- 
responds to the reflex from the plane (1231) of hexagonal cordierite lattice. This is explained by the fact that indialite and cordierite differ on XRD diagram which has at least three reflexes for cordierites and only one for indialite.

In total, the heat treatment at different temperatures has shown that ordering index increases with temperature increase and attains its maximum value at $1173 \mathrm{~K}$ for KSK-4 $\Delta \approx 0.29$ (Fig. 2) and for KSK-6 $\Delta \approx 0.30$ (Fig. 2). With the temperature increase to $1323-1373 \mathrm{~K}$ and higher temperatures, thermal motions of cations on the structure lead to new unordering and, respectively, to the decrease in ordering index and formation of eutectic system with solid solutions of $\alpha$-cordierite, mullite and spinel. For KSK-10 glass material, processes of solid solutions formation at heat treatment occur more intensively: splitting of maxima for $2 \Theta$ angles between 32 and $33^{\circ}$ is not observed (Fig. 3) in the region of the indicated temperatures. Heat treatment at $1423 \mathrm{~K}$ leads to formation of continuous solid solution of $\alpha$-cordierite in mullite, as the lines d (hkl) of $\alpha$-cordierite disappear, and only shifted diffraction maxima of mullite are identified.

Table 3

\section{Predetermined chemical composition of experimental glasses, their melting temperature and structure after melting and heat treatment}

\begin{tabular}{|c|c|c|c|c|c|c|c|c|}
\hline \multirow{3}{*}{ Symbol } & \multicolumn{5}{|c|}{ Chemical composition of model glasses, wt $\%$} & \multirow{3}{*}{$\begin{array}{c}\text { Melting } \\
\text { temperature, } \\
\mathrm{K}\end{array}$} & \multirow{3}{*}{$\begin{array}{l}\text { Sturcture of glasses after } \\
\text { the melting }\end{array}$} & \multirow{3}{*}{$\begin{array}{l}\text { Type and amount, vol } \% \text { of } \\
\text { crystalline phase after heat } \\
\text { treatment }\end{array}$} \\
\hline & \multicolumn{3}{|c|}{$\begin{array}{l}\text { Phase-forming } \\
\text { components }\end{array}$} & \multirow{2}{*}{$\begin{array}{l}\text { Crystallization } \\
\text { catalysts }\end{array}$} & \multirow{2}{*}{$\begin{array}{l}\text { Modifying } \\
\text { additives }\end{array}$} & & & \\
\hline & $\mathrm{MgO}$ & $\mathrm{Al}_{2} \mathrm{O}_{3}$ & $\mathrm{SiO}_{2}$ & & & & & \\
\hline KSK-4 & 14 & 28 & 45 & $\mathrm{TiO}_{2}, \mathrm{CeO}_{2}(5.5)$ & $\begin{array}{l}\mathrm{CaO}, \mathrm{K}_{2} \mathrm{O} \\
(7.5)\end{array}$ & 1873 & amorphous & $\begin{array}{l}\alpha \text {-cordierite-40; mullite-2; } \\
\text { spinel-2 }\end{array}$ \\
\hline KSK-6 & 13 & 22 & 49 & $\begin{array}{c}\mathrm{TiO}_{2}, \mathrm{P}_{2} \mathrm{O}_{5}, \mathrm{ZrO}_{2} \\
(12)\end{array}$ & $\mathrm{SrO}(4)$ & 1823 & amorphous & $\begin{array}{c}\alpha \text {-cordierite-25; mullite-10; } \\
\text { quartz-5 }\end{array}$ \\
\hline $\begin{array}{c}\text { KSK- } \\
10\end{array}$ & 9 & 29 & 51 & $\begin{array}{c}\mathrm{TiO}_{2}, \mathrm{ZrO}_{2} \\
\mathrm{CeO}_{2}, \mathrm{P}_{2} \mathrm{O}_{5}(6)\end{array}$ & $\mathrm{SrO}, \mathrm{B}_{2} \mathrm{O}_{3}(5) \mid$ & 1823 & microheterogeneous & mullite- 80 ; cristobalite- 2 \\
\hline
\end{tabular}

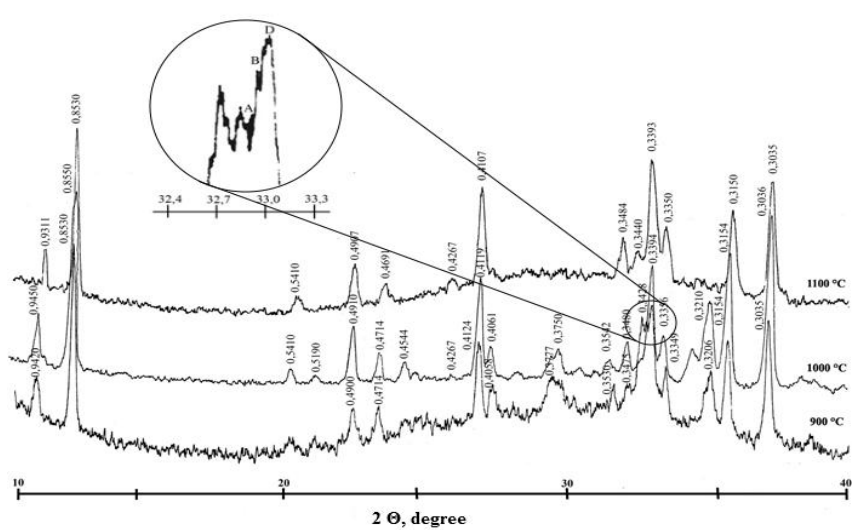

Fig. 1. XRD-diagram of experimental glass-ceramic material KSK-4 after heat treatment

Structure of KSK-6 materials after melting (Fig. $4 \mathrm{a})$ is amorphous, after heat treatment at $1373 \mathrm{~K}$ it consists of $\alpha$-cordierite crystals in the form of isometric prisms (Fig. 4b), which have hexagonal profile in crosssection view. Crystals of high-temperature cordierite have short prismatic habitus, belong to rhombic syngony and are twinned in such a way that look like hexagonal (Fig. $4 c)$. Mullite crystals observable on diffractogram are hard to identify, since thin prisms of rhombic syngony look similar to $\alpha$-cordierite on the plane (001) [11].

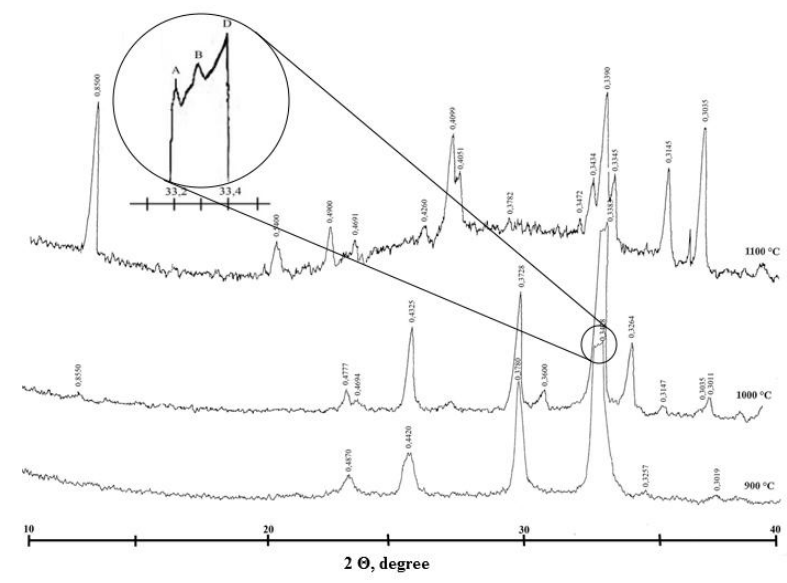

Fig. 2. XRD-diagram of experimental glass-ceramic material KSK-6 after heat treatment

The important factor of crystallization process intensification in KSK-10 glass material is the presence of sheaf-shaped mullite crystals after melting (Fig. 4d). Crystallization rate of cordierite primarily depends on the amount of mullite, because nucleation accelerates mullite crystallization and, therefore, cristobalite formation. Crystal growth in the structure of this material during heat treatment is determined by viscosity, which is $\approx 10^{9} \mathrm{~Pa} \cdot \mathrm{s}$. Such run of the curve of viscosity against temperature should be considered optimal, when its maximum is 
shifted to the temperature range below softening point, i.e. to the viscosity range above $10^{8} \mathrm{~Pa} \cdot \mathrm{s}$.

The structure of KSK-10 material after heat treatment at $1423 \mathrm{~K}$ (Fig. 4e) comprises column crystals of secondary mullite with the sizes of $\approx 1 \mu \mathrm{m}$ with rather high aspect ratio of the type II (3-10:1), which are formed on the nuclei of small cubic short-prism primary crystals of mullite with aspect ratio of the type I (1-3:1) (Fig. 4f), present in insignificant quantities in the material. Interplanar distances of short-prism and needle mullite are very close, thus it is impossible to determine the crystalline form of mullite nuclei with XRD analysis [12]. Column habitus of mullite crystals, which are closely intertwined and form crystalline concretions, allow to reinforce the glass matrix and increase thermomechanical properties of the glass ceramics.

Formation of interpenetrated ceramized structure of KSK-10 based on mullite solid solutions leads to blocking the microfractures, which significantly influence the increase of failure viscosity of the material to $3.5 \mathrm{MPa} \cdot \mathrm{m}^{1 / 2}$ and impact viscosity to $5.0 \mathrm{~kJ} / \mathrm{m}^{2}$.

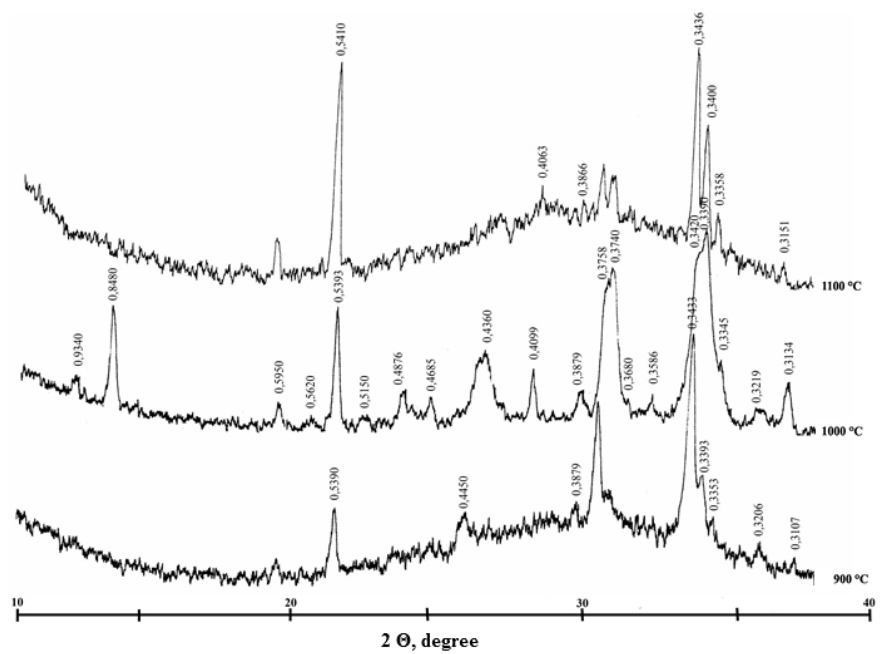

Fig. 3. XRD-diagram of experimental glass-ceramic material KSK-10 after heat treatment

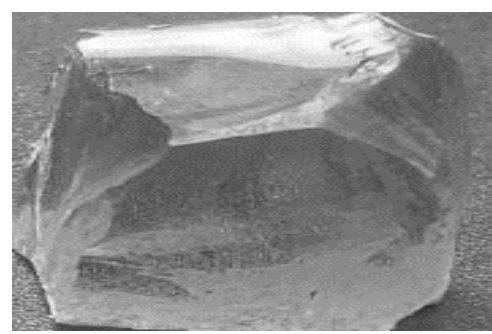

a)

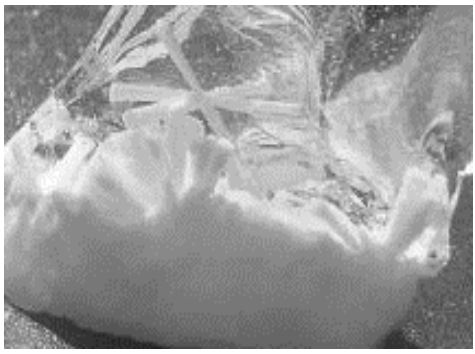

d)

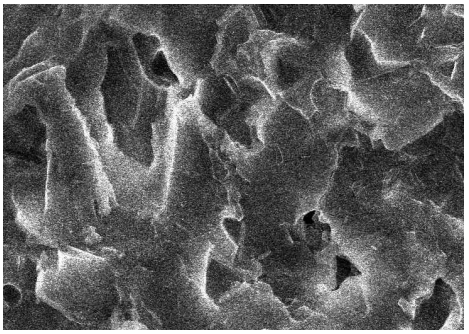

b)

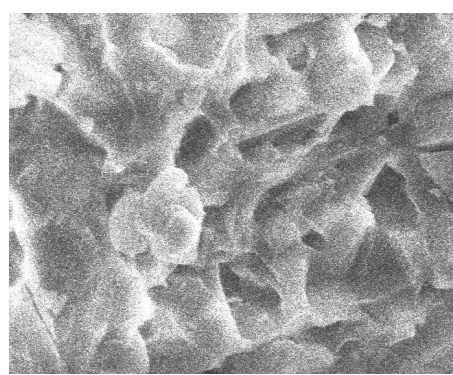

e)

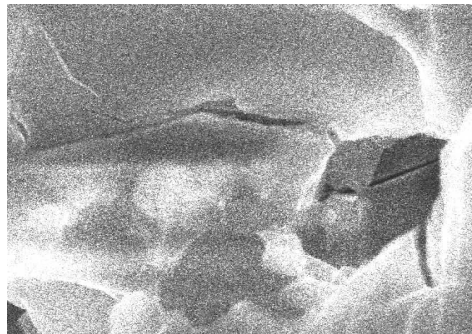

c)

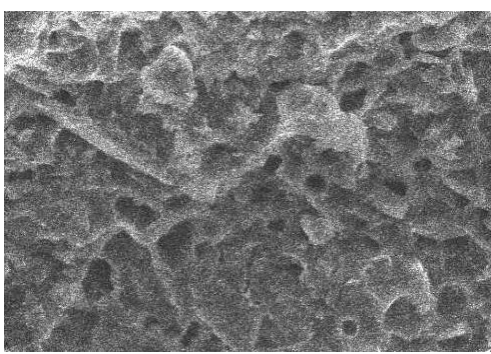

f)

Fig. 4. Structure of model glasses: KSK-6 after melting (a); KSK-6 after heat treatment (b, c); KSK-10 after melting (d) and KSK-10 after heat treatment (e, f) 


\section{Conclusions}

Viability of creating protective high-strength glassceramic materials with high impact viscosity based on magnesium aluminosilicate glasses which are used under conditions of high mechanical and thermal loads has been established. Mechanism of structure formation in the glasses of the $\mathrm{MgO}-\mathrm{Al}_{2} \mathrm{O}_{3}-\mathrm{SiO}_{2}$ system and the influence of modifying additives on the features of crystallization during heat treatment have been analyzed.

Initial magnesium aluminosilicate system and crystallization catalysts have been selected and substantiated; the model glasses have been synthesized. Influence of the type of structure ordering of glassceramic materials in a low-temperature region of nucleation and crystallization on the formation of ceramized structure has been determined. It has been established that the presence of the crystalline mullite after melting allows to form secondary column crystals of mullite in the amount of $80 \mathrm{vol} \%$ with sizes up to $1 \mu \mathrm{m}$ on the basis of primary short-prism crystals. The interpenetrated structure will allow reinforcing glass matrix and increasing thermomechanical properties of the developed glass ceramics in protective elements of special-purpose vehicles.

\section{References}

[1] Carter B., Norton G.: Ceramic Materials Science and Engineering. Springer, New York, London 2007.

[2] Beall G.: Pat. US 7465687 B2, Publ. Oct. 01, 2015.

[3] Logvinkov S.: Tverdofaznye Reakcii Obmena v Tekhnologii Keramiki. HNJeU, Kharkiv 2013.

[4] Toropov N., Poraj-Koshic E.: Strukturnye Prevrashhenia v Steklakh pri Povyshennykh Temperaturakh. Nauka, Leningrad 1965.

[5] Kranold R., Lemcbe R.: $18^{\text {th }}$ Int. Congress Glass, San Francisco, California, ICG 18 Meet. Cuide, Westerville, Ohio 1998, 59.
[6] Hong S.-H., Messing G.: J. Am. Ceramic Soc., 1997, 80, 1551. https://doi.org/10.1111/j.1151-2916.1997.tb03015.x

[7] Mirwald P.: Am. Min., 1982, 67, 277.

[8] Miyashiro A.: Am. J. Sci., 1957, 255, 43.

https://doi.org/10.2475/ajs.255.1.43

[9] Wong-Ng W., McMurdie H., Hubbard C., Mighell A.: J. Res.

Natl. Inst. Stand. Technol., 2001, 106, 1013.

https://doi.org/10.6028/jres.106.052

[10] Vogel W.: Glass Chemistry. Springer-Verlag, New York, Berlin 1994.

[11] Pimkov Ju., Filatova N., Kosenko N., Bezrukov R.: Ogneupory i Tekhn. Keramika, 2014, 4-5, 22.

[12] Al-Harbi O., Hamzawy E.: Ceram. Int., 2014, 40, 5283.

https://doi.org/10.1016/j.ceramint.2013.10.101

Received: May 08, 2019 / Revised: June 04, 2019 / Accepted: October 15, 2019

\section{МЕХАНІЗМ ФОРМУВАННЯ ТВЕРДИХ РОЗЧИНІВ В КОРДІЄРИТ-МУЛІТОВИХ СКЛОМАТЕРІАЛАХ ПРИ ЇХ СИТАЛІЗАЦЇ̈}

Анотація. Встановлено актуальність розроблення високоміцних склокристалічних покриттів за ресурсозберігаючою технологією при створенні елементів захисної дії. Проаналізовано механізм структуроутворення в магнійалюмосилікатних стеклах за умов термічного оброблення. Обтрунтовано вибір системи та розроблено модельні стекла та склокристалічні матеріали на їх основі. Досліджено закономірності впорядкованості структури та формування фазового складу склокристалічних матеріалів за їх ситалізації. Встановлено, що наявність кристалічної фази муліту після варіння приводить до появи первинних кристалів та формування тонкокристалічної структури з наявністю стовбчастих кристалів муліту за умов низькотемпературного термічного оброблення на стадії зародкоутворення. Розроблені високоміцні склокристалічні матеріали можуть бути використані як основа при створенні захисних елементів для спеціальної техніки за енергозберігаючою технологією.

Ключові слова: склокераміка, структура, тверді розчини, кордієрит, муліт, упорядкування, термічне оброблення. 